\title{
PERILAKU ZAKAT ELIT AGAMA KOTA MALANG (Studi tentang Konstruk Elit Agama Kota Malang terhadap Zakat Profesi)
}

\author{
Fakhruddin dan Erik Sabti Rahmawati \\ Fakultas Syari'ah UIN Maulana Malik Ibrahim Malang \\ erickrahma@yahoo.com
}

\begin{abstract}
Abstrak
This research focusing on the understanding of zakat-profession according to religious elite in Malang City and how they manage to pay zakat-profession. The result from research and analyzed data explain that zakat-profession according to religious elite in Malang City is charity that should be paid by people who has the specific income which meet the minimum nashab and haul (meet one year minimum). The construct of religious elite in zakat profession describe that all sect; even from Muhammadiyah, Nahdlatul Ulama', and Indonesian Ulema Council state that the legal provision of zakat-profession is Wajib. This verdict related to the general lafadz about zakat obligation in Al-Qur'an and qiyas aulawi to the lafadz of zakat-agriculture obligation. In determining nashab of zakat-profession they agreed in using the analogy of zakat-gold and zakat-trade. But they differ in specific percentage. Muhammadiyah states that the percentage of zakat-profession is $2.5 \%$, Nahdlatul Ulama' states that the percentage is around 2.5\%-3.3\%, and Indonesian Ulema Council states two opinions carefully (ihtiyâth), both are $2.5 \%$ and $2.5 \%-5 \%$. Moreover, the implementation of zakat-profession does not wait neither the minimum nashab nor haul, but people can pay it every time they get their income.
\end{abstract}

Penelitian ini fokus pada pemahaman tentang zakat profesi menurut elit agama Kota Malang, dan bagaimana konstruk elit agama Kota Malang dalam menunaikan zakat profesi. hasil penelitian dan analisis data, sesuai dengan rumusan penelitian yang diajukan di awal, peneliti menarik beberapa kesimpulan sebagai berikut: Zakat profesi menurut elit agama kota Malang adalah zakat yang wajib dikeluarkan oleh seseorang dengan penghasilan tertentu setelah mencapai nishab dan haul (dalam jangka waktu satu tahun). Konstruks elit agama kota Malang terhadap zakat profesi adalah: Semua subyek penelitian, baik dari Muhammadiyah, Nahdlatul Ulama', dan Majelis Ulama' Indonesia menyatakan bahwa zakat profesi hukumnya wajib. Hal ini didasarkan atas keumuman lafadz tentang perintah zakat dalam al-Qur'an dan qiyas aulawi terhadap lafadz tentang perintah zakat pertanian. sedangkan Dalam menentukan nisab untuk zakat profesi semua berpandangan bahwa zakat profesi diqiyaskan dengan zakat emas dan perdagangan. Hanya saja terdapat perbedaan dalam prosentasenya. Muhammadiyah menyatakan bahwa prosentase zakat profesi sebanyak 2,5\%. Sedangkan dari Nahdlatul Ulama' menyatakan bahwa prosentasenya mulai 2,5\%-3,3\%. Sementara itu, untuk MUI terdapat dua pandangan, yaitu 2,5\% dan 2,5\% - 5\% untuk kehatia-hatian (ihtiyath). Adapun waktu pelaksanaan zakat profesi, yaitu tidak menunggu nishab dan haul tetapi langsung pada waktu menerima penghasilan.

Kata Kunci: zakat profesi, mustahiq, muzakki, nishab. 
Dalam penelitian tentang zakat, Yusuf Qardhawi merupakan peneliti awal yang meneliti zakat secara lengkap ${ }^{1}$. Setelah itu, penelitian tentang zakat semakin menarik perhatian umat Islam terutama di Indonesia dengan berkembangnya wacana ekonomi Islam. Berdasarkan kajian yang dilakukan oleh para ahli tentang zakat ini dapat dikategorikan ke dalam beberapa tipologi, yaitu; pertama, kajian zakat dari aspek manajemennya, seperti kajian Yahmin Haddad ${ }^{2}$, Eri Sudewo ${ }^{3}$ dan Maskur Malaka ${ }^{4}$. Kedua, zakat dalam kaitannya dengan pajak, seperti Syekhul Hadi ${ }^{5}$, Sudirman ${ }^{6}$, Nuruddin Mhd. Ali ${ }^{7}$. Ketiga, pengaruh dan

${ }^{1}$ Yusuf al-Qardhawi, Fiqh al-Zakah, Dirâsah Muqâranah al-Ahkâmihâ wa Falsafatihâ fî Dhaui al-Qur'an wa al-Sunnah. Dalam disertasi ini, Yusuf memberikan kesimpulan bahwa zakat bukanlah ibadah mahdhah semata akan tetapi zakat adalah ibadah yang bersifat sosial ekonomi (ibadah maliyah ijtimaiyyah). Di samping itu, Yusuf mengatakan bahwa zakat adalah sistem keuangan, ekonomi, sosial, politik, moral dan agama sekaligus.

${ }^{2}$ Yahmin Haddad, Dinamika Pengelolaan Zakat di Desa Putukrejo Gondanglegi Malang. Penelitian ini menggambarkan pengelolaan zakat di Putukrejo Malang dengan kolaborasi antara ulama, umara' dan aghniyah'.

${ }^{3}$ Eri Sudewo, Manajemen Zakat, Tinggalkan 15 Tradisi, Terapkan 4 Prinsip Dasar. Menurut Eri bahwa zakat tidak banyak berdampak pada peningkatan kualitas kehidupan kaum miskin karena pengelolaan zakat oleh lembaga zakat masih menggunakan manajemen tradisional.

${ }^{4}$ Maskur Malaka, Strategi Pemberdayaan Zakat (Studi Kasus BAZDA Sulawesi Tenggara. Dalam penelitian ini disebutkan bahwa perlu adanya kaiatan antara pengelola zakat (BAZDA) dengan lingkungan dan juga memanfaatkan kekuatan pengungkit (highest levarage) sehingga pengumpulan zakat betul-betul maksimal.

${ }^{5}$ Syekhul Hadi Permono, Pendayagunaan Zakat dalam Pembangunan Nasional, Persamaan dan Perbedaannya dengan Zakat. Dalam penelitian ini, disebutkan bahwa zakat dan pajak adalah dua hal yang berbeda, meskipun memiliki persamaan. Oleh karena itu, maka zakat tidak bisa menghapus pajak dan begitu juga sebaliknya. Di samping itu juga disebutkan bahwa Indonesia yang berdasarkan Pancasila termasuk negara Islam. Oleh karena itu, maka pemerintah Indonesia berhak bahkan berkewajiban mengelola zakat.

${ }^{6}$ Sudirman, Relasi Zakat dan Pajak, Studi tentang Zakat sebagai Pengurang Penghasilan Kena Pajak (PKP). Hasil dari penelitian ini mengungkapkan bahwa pelaksanaan zakat sebagai pengurang penghasil kena pajak belum maksimal disebabkan karena kurangnya sosialisasi kepada masyarakat.

${ }^{7}$ Nuruddin Mhd. Ali, Zakat Sebagai Instrumen dalam Kebijakan Fiskal. Penelitian ini menyimpulkan dampak zakat bagi kesejahteraan masyarakat miskin, seperti Multipiah ${ }^{8}$, dan Rafiqah Ahmad Hamzah9. Keempat, kritik terhadap pemahaman zakat, seperti Abdurrachman Qadir ${ }^{10}$ dan Madsar F. Mas'udi ${ }^{11}$.

Penelitian-penelitian di atas belum ada yang menggambarkan perilaku zakat kalangan elit agama. Kajian yang dilakukan oleh para ahli kebanyakan berkisar pada manajemen zakat termasuk hubungannya dengan pajak, seperti Yahmin Haddad, Eri Sudewo, Maskur Malaka, Syekhul Hadi, Sudirman, dan Nuruddin Mhd. Ali. Sementara itu penelitian yang dilakukan oleh Multipiah dan Rafiqh Ahmad Hamzah fokus pada pengaruh dan dampak yang ditimbulkan oleh zakat dan penelitian yang dilakukan oleh Qadir dan Masdar mengarah pada kritik atas pemahaman masayarakat Islam terhadap ajaran zakat.

Dalam salah satu pengamatan terhadap perilaku zakat elit agama Kota Malang ditemukan bahwa zakat dikeluarkan secara langsung ketika mendapatkan penghasilan

bahwa untuk pengintegrasian zakat dan pajak perlu melakukan rekonstruksi sejarah terhadap pelaksanaan zakat pada masa awal Islam, di samping memahami evolusi pemaknaan pajak.

${ }^{8}$ Multipiah, Peran "ZIS" terhadap Kesejahteraan Rumah Tangga Miskin (Studi Penanggulangan Kemiskinan Melalui Bantuan Modal, Pendidikan dan Kesehatan di Daerah Malang. Kesimpulan dari penelitian ini adalah ZIS tidak berpengaruh terhadap peningkatan kesejahteraan Rumah Tangga Muslim yang Miskin. Hal ini disebabkan karena jumlah bantaun sangat kecil dan parsial. Di samping itu juga disebakan karena tidak adanya program pembinaan intensif.

${ }^{9}$ Rafiqah Ahmad Hamzah, Dampak Zakat Produktif terhadap Pemberdayaan Ekonomi dan Faktor-Faktor Keberhasilan Usaha Mustahik (Studi Kasus Pendayagunaan Zakat Produktif oleh Dompet Dhuafa'). Dalam penelitian ini disimpulkan bahwa program pendampingan yang dilakukan oleh Dompet Dhuafa' melalui Masyarakat Mandiri dapat memberdayakan dan memperbaiki ekonomi mustahik.

${ }^{10}$ Abdurrachman Qadir, Zakat dalam Dimensi Mahdhah dan Sosial. Menurut Qadir bahwa persepsi sebagian masyarakat tentang konsep teoritik zakat belum akurat sehingga dalam penerapan konsep operasionalnya tampak belum konsisten dengan esensi, fungsi, dan tujuan zakat yang berlandaskan normatif, historis, dan filosofis dan bersifat ilzami-ijbari sehingga zakat belum berfungsi mewujudkan tujuannya.

${ }^{11}$ Masdar F. Mas'udi, Menggagas Ulang Zakat sebagai Etika Pajak dan Belanja Negara untuk Rakyat. 
tanpa memperhatikan nishab dan haulnya ${ }^{12}$. Hal ini menimbulkan pertanyaan, kenapa elit agama kota Malang mengeluarkan zakat dari harta yang diperoleh secara langsung tanpa memperhatikan nishab dan haul yang semestinya harus diperhatikan, bagaimana pemahaman tentang zakat profesi menurut elit agama Kota Malang, dan bagaimana konstruk elit agama Kota Malang dalam menunaikan zakat profesi?

Penelitian ini diharapkan dapat memberikan kontribusi pemikiran zakat di Indonesia. Kontribusi tersebut bisa bersifat teoritis maupun praktis. Sumbangan yang bersifat teoritis yaitu berupa alternatif penjelasan yang lebih konkrit berdasarkan data lapangan tentang konstruk elit agama terhadap zakat profesi. Hal bisa dijadikan sebagai bahan pertimbangan untuk membuat kebijakan terutama bagi pengelola zakat. Di samping itu, penelitian ini akan memberikan sumbangan pemikiran bagi peneliti selanjutnya dan memperkaya wawasan khususnya masalah zakat profesi. Sedangkan yang bersifat praktis diharapkan dapat memberikan kontribusi praktis bagi umat Islam secara umum dan elit agama secara khusus dalam memberikan alternatif-alternatif solusi bagi permasalahan umat Islam Indonesia khususnya masalah zakat profesi.

\section{Metode Penelitian}

Penelitian ini dilakukan di Wilayah Kota Malang yang melibatkan para tokoh agama Islam dari Majelis Ulama Indonesia Kota Malang, Pimpinan Daerah Muhammadiyah Kota Malang, dan Pengurus Cabang Nahdhatul Ulama Kota Malang sebagai subyek penelitian.

Penelitian ini menggunakan metode kualitatif yang juga berdasar pada pendekatan

${ }^{12} \mathrm{Nishab}$ adalah batas minimal harta yang fenomenologi. Suatu pendekatan yang dipelopori oleh Edmund Husserl (1859-1938) yang dikembangankan dari penelitian filosofis. Pendekatan ini dimaksudkan untuk menentukan metode filosofis ilmiah yang lepas dari segala prasangka metafisis. ${ }^{13}$

\section{Hasil dan Pembahasan}

\section{Kondisi Obyektif Kota Malang Sebagai Lokasi Penelitian}

Kota Malang terletak di tengah-tengah wilayah Kabupaten Malang yang secara astronomis terletak pada posisi $112.06^{\circ}-112.07^{\circ}$ Bujur Timur, $7.06^{\circ}-8.02^{\circ}$ Lintang Selatan. Luas wilayah Kota Malang sebesar 110,06 km² yang terbagi dalam lima kecamatan yaitu: a) Kecamatan Kedungkandang; b) Kecamatan Sukun; c) Kecamatan Klojen; d) Kecamatan Blimbing; dan e) Kecamatan Lowokwaru.

Potensi alam yang dimiliki Kota Malang adalah letaknya yang cukup tinggi yaitu 440 - 667 meter di atas permukaan air laut. Salah satu lokasi yang paling tinggi adalah Pegunungan Buring yang terletak di sebelah timur Kota Malang. Dari atas pegunungan ini terlihat jelas pemandangan yang indah antara lain dari arah Barat terlihat barisan Gunung Kawi dan Panderman, sebelah utara Gunung Arjuno, sebelah Timur Gunung Semeru dan jika melihat ke bawah terlihat hamparan Kota Malang. Sedangkan sungai yang mengalir di wilayah Kota Malang adalah Sungai Brantas, Amprong dan Bango.

Adapunjumlah penduduk menurut agama dan kecamatan dapat dilihat dalam tabel berikut:

${ }^{13}$ Dr.Anton Bakker, Metode-Metode Filsafat, (Jakarta: Ghalia Indoneesia, 1984), 110. 
Tabel 1

Jumlah Penduduk menurut Agama dan Kecamatan

\begin{tabular}{lllllll}
\hline \multirow{2}{*}{ Kecamatan } & \multicolumn{7}{c}{ Agama } \\
\cline { 2 - 7 } & \multicolumn{1}{c}{ Islam } & Kristen & Katolik & Hindu & Budha & Lain-lain \\
\hline Kedungkandang & 152,228 & 7,206 & 3,231 & 579 & 331 & 74 \\
\hline Sukun & 156,276 & 8,988 & 8,087 & 8,087 & 2,615 & - \\
\hline Klojen & 113,829 & 8,335 & 9,511 & 1,388 & 1,388 & 177 \\
\hline Blimbing & 131,407 & 20,535 & 15,597 & 1,780 & 1,575 & 65 \\
\hline Lowokwaru & 15,307 & 1,197 & 2,060 & 26 & 13 & - \\
\hline
\end{tabular}

Kota Malang adalah kota terbesar kedua di Jawa Timur setelah Surabaya. Kota ini juga dikenal dengan berbagai sebutan, seperti kota pendidikan, kota pariwisata, kota militer dan sejarah, kota bunga, kota industri, Paris of Java dan sebagainya. Kota Malang disebut sebagai kota pendidikan, karena banyaknya fasilitas pendidikan yang tersedia dari mulai tingkat Taman Kanak-kanak, Sekolah Dasar sampai
Pendidikan Tinggi dan jenis pendidikan nonformal seperti kursus bahasa asing dan kursus komputer, baik yang diselenggarakan oleh pemerintah maupun swasta. Gambaran nyata mengenai jumlah sekolah, baik negeri maupun swasta di bawah Kementerian Pendidikan Nasional dan Kementerian Agama di Kota Malang dapat dilihat pada tabel berikut:

Tabel 2

Jumlah Sekolah Negeri dan Swasta

\begin{tabular}{lllllll}
\hline \multirow{2}{*}{ No } & \multirow{2}{*}{ Kecamatan } & \multicolumn{5}{c}{ Sekolah } \\
\cline { 3 - 7 } & & TK & SD/MI & \multicolumn{2}{c}{ SMP/MTs } & SMA/MA \\
\hline 1. & Kedungkandang & 49 & $49 / 20$ & $15 / 8$ & $5 / 3$ & 6 \\
\hline 2. & Sukun & 59 & $59 / 12$ & $17 / 3$ & $8 / 1$ & 10 \\
\hline 3. & Klojen & 70 & $70 / 6$ & $24 / 5$ & $20 / 4$ & 10 \\
\hline 4. & Blimbing & 56 & $56 / 5$ & $18 / 2$ & $6 / 1$ & 9 \\
\hline 5. & Lowokwaru & 59 & $59 / 5$ & $15 / 6$ & $10 / 4$ & 9 \\
\hline Jumlah & 293 & $265 / 48$ & $89 / 24$ & $49 / 13$ & 44 \\
\hline
\end{tabular}

Dari tabel di atas, dapat dilihat bahwa pada tingkat Taman Kanak-Kanak (TK) jumlah sekolah sebanyak 293. Pada tingkat Sekolah Dasar (SD) jumlah sekolah yang ada sebanyak 265. Sedangkan jumlah Sekolah Menengah Pertama (SMP) sebanyak 89 sekolah, Sekolah Menengah Umum (SMU) sebanyak 49 sekolah dan Sekolah Menengah Kejuruan (SMK) sebanyak 44 sekolah. Adapun jumlah sekolah di lingkungan Kementerian Agama tahun 2008/2009 menunjukkan jumlah Madrasah Ibtidaiyyah (MI) sebanyak 48 unit, Madrasah Tsanawiyah (MTs) sebanyak 24 unit dan Madrasah Aliyah (MA) sebanyak 13 unit.

Perguruan Tinggi Negeri (PTN) di Kota Malang sebanyak 4 PTN yaitu Universitas Brawijaya (UNIBRAW), Universitas Negeri Malang (UM), Universitas Islam Negeri (UIN)
Maulana Malik Ibrahim Malang dan Politeknik Kesehatan Malang.

Adapun pondok pesantren berdasarkan data dari Kementerian Agama, terdapat kenaikan jumlah yang terdaftar di Kementerian Agama dibandingkan tahun sebelumnya seperti pada tabel berikut:

Tabel 3

Jumlah Pondok Pesantren

\begin{tabular}{lllll}
\hline \multirow{2}{*}{ No } & \multirow{2}{*}{ Kecamatan } & \multicolumn{3}{c}{$\begin{array}{c}\text { Banyaknya Pondok } \\
\text { Pesantren }\end{array}$} \\
\cline { 3 - 5 } & & $\mathbf{2 0 0 7}$ & $\mathbf{2 0 0 8}$ & $\mathbf{2 0 0 9}$ \\
\hline 1. & Kedungkandang & 13 & 15 & 13 \\
\hline 2. & Sukun & 6 & 7 & 9 \\
\hline 3. & Klojen & 6 & 6 & 4 \\
\hline 4. & Blimbing & 6 & 6 & 5 \\
\hline 5. & Lowokwaru & 16 & 16 & 17 \\
\hline Jumlah & 47 & 50 & 48 \\
\hline
\end{tabular}


Peningkatan jumlah lembaga pendidikan agama Islam dan pesantren menunjukkan kesadaran beragama yang meningkat, yang itu juga akan berimplikasi pada kesadaran untuk mengeluarkan zakat.

\section{Zakat profesi dalam pemahaman elit Agama Kota Malang}

\section{Elit Agama Muhammadiyah}

Dalam menentukan subyek penelitian dari elit agama Muhammadiyah ini, didasarkan pada izin dan rekomendasi yang diberikan oleh Pimpinan Daerah Muhammadiyah cabang Malang. Setelah peneliti mengajukan surat izin penelitian dan memaparkan tentang tujuan penelitian kepada Pimpinan Daerah Muhammadiyah cabang Malang, ditentukan 2 orang untuk subyek penelitian ini yaitu Abdul Haris dan Sunkanah.

Drs. Abdul Haris, M.A. lahir di Bojonegoro, 17 April 1967. Beliau adalah dosen Fakultas Agama Islam di Universitas Muhammadiyah Malang. Pendidikan kesarjanaannya dimulai dengan S1 Pendidikan Bahasa Arab di IAIN Sunan Ampel Malang, 1985-1989, kemudian ia melanjutkan pendidikan Pascasarjana dengan konsentrasi yang sama Pendidikan Bahasa Arab di Khourtum International Institute For Arabic Language Khartum Sudan, 1994-1996. Saat ini beliau membina beberapa matakuliah antara lain:Hadits I, Hadits II, Ulumul Hadits, dan Bahasa Arab. ${ }^{14}$

Sunkanah, M.H. lahir di Lamongan 7 Juni 1944, beliau adalah pensiunan hakim yang saat ini menjadi dosen luar biasa di Fakultas Agama Islam di Universitas Muhammadiyah Malang. Pendidikan Sarjana S1 ditempuh di Fakultas Syariah IAIN Sunan Kalijaga Yogyakarta, sedangkan untuk S2 ditempuh di Pascasarjana Hukum Agraria Universitas Brawijaya Malang. Beliau adalah aktifis Aisyiah Muhammadiyah, yang sudah lebih dari 40 tahun dia berkarir di Muhammadiya. Saat ini ia menjabat sebagai

\footnotetext{
${ }^{14}$ Wawancara dengan Abdul Haris pada tgl 27 Oktober 2011, di Kantor FAI Universitas Muhammadiyah Malang.
}

Ketua bagian tablig Aisyiah Pengurus Daerah Muhammadiyah Malang. ${ }^{15}$

Abdul Haris, ketika ditanya tentang zakat profesi mengemukakan bahwa penghasilan yang berasal dari profesi dikalangan masyarakat Muhammadiyah adalah bagian dari harta benda yang harus dikeluarkan zakatnya. Menurutnya hal ini didasarkan pada prinsip-prinsip umum ayat-ayat tentang zakat, ${ }^{16}$ seperti wa âtû haqqahu yauma hashadihi dalam Q.S. al-An'am [6]: 141

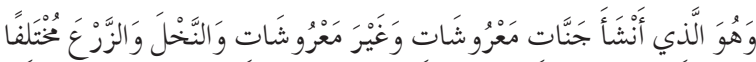

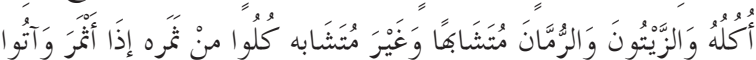

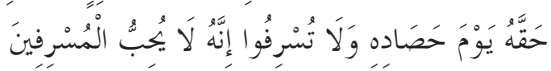

Artinya: Dan Dialah yang menjadikan kebun-kebun yang berjunjung dan yang tidak berjunjung, pohon korma, tanam-tanaman yang bermacam-macam buahnya, zaitun dan delima yang serupa (bentuk dan warnanya) dan tidak sama (rasanya). makanlah dari buahnya (yang bermacam-macam itu) bila Dia berbuah, dan tunaikanlah haknya di hari memetik hasilnya (dengan disedekahkan kepada fakir miskin); dan janganlah kamu berlebih-lebihan. Sesungguhnya Allah tidak menyukai orang yang berlebih-lebihan.

Dan ayat yang menyatakan wa fi amwâlihim haqqun li as-saili wa al-mahrumi dalam Q.S. Azd-Dzariyat [51]: 19.

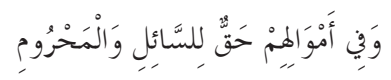

Artinya: Dan pada harta-harta mereka ada hak untuk orang miskin yang meminta dan orang miskin yang tidak mendapat bagian.

Ketika ditanyakan lebih lanjut tentag dasar hukum yang digunakan, Abdul Haris mengatakan: ${ }^{17}$

"Saya cenderung mengikuti pendapat Qardhawi karena dia memberikan ketentuan tidak terlalu ketat juga tidak terlalu longgar. Menurut Yusuf Qardhawi semua bentuk penghasilan yang produktif, harus dikeluarkan zakatnya, apabila tidak dikeluarkan maka prinsip keadilan dalam Islam itu tidak jalan. Misalnya, akan sangat tidak adil kalau seorang

\footnotetext{
${ }^{15}$ Wawancara dengan Sunkanah pada tanggal 28 Oktober 2011 di kediamannya Jl. Soponyono 23 Singosari Malang.

${ }^{16}$ Wawancara dengan Abdul Haris...

${ }^{17}$ Wawancara dengan Abdul Haris...
} 
profesor atau doktor yang kerjanya tidak terlalu berat dan penghasilannya sebulan bisa mencapai 9 juta tidak diwajibkan mengeluarkan zakat, sedangkan petani yang saat ini susah payah, bekerja keras, harga pupuk mahal, harus membayar irigasi ia diwajibkan mengeluarkan zakat". ${ }^{18}$

Selanjutnya Sunkanah, ketika ditanyakan tentang hukum zakat profesi, beliau mengungkapkan pemahamannya dengan mengatakan: ${ }^{19}$

"Tidak semua penghasilan profesi wajib dizakati, melihat besar kecilnya penghasilan itu. Kalau saya mengatakan bahwa semua penghasilan itu wajib zakat, bagaimana dengan orang-orang yang punya penghasilan tetapi tidak mencukupi kebutuhan sehariharinya. Penghasilan PNS kan juga ada golongan I sampai golongan IV. Jadi harus ada standar yang jelas. Kalau di Universitas itu kan ada tukang sapu sampai rektor, masing-masing pendapatannya berbeda. Tetapi, bukan berarti golongan menengah ke bawah itu tidak punya penghasilan lain, mungkin juga bisa diambil zakatnya, kalau memenuhi standar minimal dan kebutuhannya tercukupi, cukup atau tidaknya kebutuhan setiap orang per bulan kan relatif."

Menurut Sunkanah kalau melihat dalildalil dalam Al-Quran atau hadits memang tidak ada yang menyebutkan secara eksplisit, tetapi kita bisa menjadikan dalil-dalil zakat yang umum sebagai pijakan. ${ }^{20}$ Seperti dalam Q.S. at-Taubah: 103

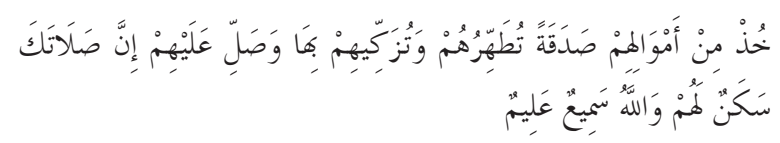

Artinya: Ambillah zakat dari sebagian harta mereka, dengan zakat itu kamu membersihkan dan mensucikan mereka dan mendoalah untuk mereka. Sesungguhnya doa kamu itu (menjadi) ketenteraman jiwa bagi mereka. dan Allah Maha mendengar lagi Maha mengetahui.

Lebih lanjut Sunkanah menguraikan pemahaman terhadap ayat diatas, dalam ayat itu dengan tegas disebutkan bahwa fungsi zakat adalah untuk membersihkan harta dan beribadah kepada Allah. Inilah yang saya jadikan dasar dalam mengeluarkan zakat

\footnotetext{
${ }^{18}$ Wawancara dengan Abdul Haris ...

${ }^{19}$ Wawancara dengan Sunkanah...

${ }^{20}$ Wawancara dengan Sunkanah...
}

dan seharusnya juga menjadi dasar bagi umat Islam yang lain.

Dalam uraian data diatas dapat dianalisis bahwa hukum zakat profesi menurut elit agama Muhammadiyah tidak ada perbedaan, yaitu wajib bagi setiap muslim yang mempunyai penghasilan yang berasal dari profesi, walaupun tidak ada teks yang ekplisit menjelaskan tentang kewajiban zakat profesi tersebut. Adapun dalil teks yang dapat digunakan sebagai dasar hukum kewajiban zakat profesi adalah keumuman dari ayat-ayat tentang zakat.

Ayat-ayat tentang zakat yang dijadikan dasar atau landasan hukum oleh kedua elit agama tersebut berbeda walaupun berimplikasi sama tentang kewajiban zakat profesi. Abdul Haris menggunakan Q.S. al-An'am [6]: 141 sebagai dasar hukum, dengan mengambil keumuman dari ayat itu yang berisi perintah kepada umat Islam untuk mengeluarkan zakat setiap menerima hasil, walaupun ayat ini secara khusus menjelaskan tentang perintah zakat kepada para petani setiap memetik hasil pertanian mereka.

Abdul Haris menggunakan ayat tersebut sebagai dasar hukum dengan mempergunakan pertimbangan logis, atau yang dalam Islam dikenal dengan istilah Qiyas, petani yang memperoleh hasil berkat kerja keras yang berat dan modal yang tidak sedikit serta resiko yang tidak ringan diwajibkan mengeluarkan zakat, apalagi orang yang menerima penghasilan dari profesi yang dijalankannya, seperti dokter, dosen, pengacara, hakim atau pegawai pemerintahan yang notabene kerjanya lebih ringan dari petani juga kadar resikonya sangat ringan, dapat dipastikan bahwa mereka juga terkena kewajiban zakat, demi keadilan dan pemerataan. ${ }^{21}$

Sedangkan Sunkanah, menggunakan Q.S. at-Taubah: 103 sebagai pijakan hukum kewajiban zakat dengan menekankan pada keumuman ayat ini yang menegaskan tentang fungsi dari zakat yaitu untuk membersihkan dan menyucikan harta yang kita peroleh, yang

\footnotetext{
${ }^{21}$ Wawancara dengan Abdul Haris...
} 
disini maknanya berarti bahwa kebaikan dari menunaikan zakat itu selain untuk mustahiq juga akan kembali pada muzakki. Sehingga seharusnya orang yang menunaikan zakat tidak menganggap zakat sebagai beban karena hal tersebut adalah investasi kebaikan yang hasilnya akan kembali kepada mereka. ${ }^{22}$

\section{Elit Agama Nahdhatul Ulama}

Sebagaimana elit agama dari Muhammadiyah, subyek penelitian dari elit agama Nahdlatul Ulama juga direkomendasikan oleh Pengurus Cabang Nahdlatul Ulama Malang, yaitu: K.H Dahlan Tamrin sebagai anggota dewan Muhtasyar PCNU Malang dan K.H. Muzakki sebagai pengurus Syuriah PCNU Malang.

Dr. H. Dahlan Tamrin, M.Ag. lahir di Malang 24 Maret 1950, beliau adalah dosen tetap Fakultas Syariah UIN Maulana Malik Ibrahim Malang. Pendidikan S1diselesaikan di Fakultas Tarbiyah IAIN Sunan Ampel Malang, dan S2 Hukum Islam diselesaikan di Universitas Islam Malang. Adapun gelar Doktor ia peroleh dari IAIN Sunan Ampel Surabaya dengan konsentrasi Pemikiran Islam. Beliau pernah menjabat sebagai dekan Fakultas Syariah UIN Maulana Malik Ibrahim Malang periode tahun 2004 - 2009, dan saat ini menjabat sebagai ketua Program Studi Akhwal asy-Syakhsiyyah pascasarjana UIN Maulana Malik Ibrahim Malang. ${ }^{23}$

Dr. H. Muzakki lahir di Bangkalan 25 April 1969, beliau adalah dosen tetap Fakultas Humaniora dan Budaya UIN Maulana Malik Ibrahim Malang. Sarjana SI untuk bidang pendidikan Bahasa Arab diperoleh dari IAIN Sunan Ampel Malang (sekarang menjadi UIN Maulana Malik Ibrahim Malang), kemudian beliau melanjutkan S2 Pengkajian Islam di pascasarjana UIN Syarif Hidayatullah Jakarta, dan gelar doctor dia peroleh dari IAIN Sunan Ampel Surabaya. Muzakki sejak mahasiswa sudah menjadi aktifis NU, dia meniti karir di

\footnotetext{
${ }^{22}$ Wawancara dengan Sunkanah...

${ }^{23}$ Wawancara dengan Dr. KH. Dahlan Tamrin pada tanggal 23 Oktober 2011 di kantor Pascasarjana UIN Maulana Malik Ibrahim Malang.
}

NU kurang lebih selam 15 tahun, saat ini ia menjabat sebagai dewan Syuriah PCNU Malang dan juga menjabat sebagai ketua Jurusan Sastra Arab Fakultas Humaniora dan Budaya UIN Maulana Malik Ibrahim Malang. ${ }^{24}$

Dahlan Tamrin menyatakan bahwa setiap penghasilan yang diperoleh wajib dikeluarkan zakatnya. sehingga dia tidak akan mengeluarkan infaq sebelum mengeluarkan zakat. Sebab, kita tidak boleh melakukan yang tidak wajib terlebih dahulu, sementara yang wajib belum dilakukan. ${ }^{25}$ Nash yang beliau gunakan sebagai dasar hukum kewajiban zakat penghasilan yang diperoleh dari profesi terdapat dalam Q.S. Al-Baqarah [2]: 267 yang berbunyi:

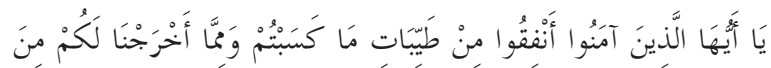

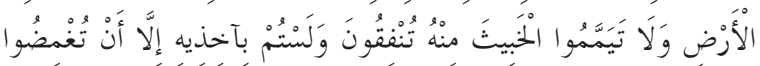

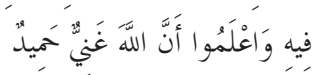

Artinya: Hai orang-orang yang beriman, nafkahkanlah (di jalan Allah) sebagian dari hasil usahamu yang baikbaik dan sebagian dari apa yang Kami keluarkan dari bumi untuk kamu. dan janganlah kamu memilih yang buruk-buruk lalu kamu menafkahkan daripadanya, Padahal kamu sendiri tidak mau mengambilnya melainkan dengan memincingkan mata terhadapnya. dan ketahuilah, bahwa Allah Maha Kaya lagi Maha Terpuji.

Lebih lanjut Dahlan Tamrin menjelaskan pemahamannya terhadap penafsiran ayat tersebut:

"Kata anfiqû min thayyibati ma kasabtum menjelaskan bahwa setiap pekerjaan yang baik harus dikeluarkan zakatnya. Pegawai negeri, dokter, dosen, pengacara dan profesi yang lain yang merupakan pekerjaan yang baik, maka juga terkena khitob wajib zakat dari ayat ini. Kata anfiqû dalam ayat ini merupakan kata perintah. Dengan menggunakan kaidah al-ashlu lil amri lil wujub, maka setiap penghasilan yang baik wajib hukumnya untuk zakat". ${ }^{26}$

\footnotetext{
${ }^{24}$ Wawancara dengan Dr. H. Muzakki pada tanggal 24 Oktober 2011, di kediamannya Rumah Dinas Pengasuh Ma'had Sunan Ampel al-'Ali UIN Maulana Malik Ibrahim Malang.

${ }^{25}$ Wawancara dengan Dr. KH. Dahlan ...

${ }^{26}$ Wawancara dengan Dr. KH. Dahlan ...
} 
Dalam pemaparan data terlihat bahwa Dahlan membedakan antara zakat dan shodaqoh. Mengenai definisi zakat dan shodaqah ini memang ada perbedaan, ada yang mengatakan bahwa zakat tidak sama dengan shadaqah, zakat adalah kewajiban yang dikenakan kepada benda-benda tertentu yang mencapai persyaratan tertentu, sedangkan shadaqah adalah pemberian seseorang terhadap orang lain tanpa mempertimbangkan syarat-syarat tertentu dan penerimanya tidak ditentukan sebagaimana zakat, diserahkan kepada orang yang mengeluarkan shadaqah. Sedangkan pendapat yang lain mengatakan bahwa zakat dan shadaqah adalah sama, yaitu harta yang dikeluarkan oleh muslim untuk memenuhi kewajiban mengeluarkan sebagian harta yang dimilikinya untuk fakir miskin.

Sedikit berbeda dengan Dahlan Tamrin, menurut Muzakki ada dua model pemikiran tentang zakat di kalangan ulama NU. Ada kelompok tradisional yang berpegang teguh pada kitab-kitab klasik, seperti pandangan Imam Syafi'I dan lain-lain, ada juga kelompok modern yang terpengaruh dan terinspirasi oleh pandangan ulama-ulama kontemporer, seperti Yusuf Qarhawi atau Tholhah Hasan. Terkait dengan hal tersebut beliau mengatakan:

"Saya bisa didua sisi itu, kalau zakat fitrah dan zakat lain saya mengikuti pandangan tradisional, tetapi untuk zakat profesi atau zakat mal, saya mengikuti pendapat yang kontemporer." 27

Menurut Muzakki zakat profesi itu sama dengan zakat mal, yaitu mempertimbangkan haul dan harus mencapai satu nishab. Tetapi dia kurang sependapat dengan praktik pemotongan zakat yang dilakukan oleh lembaga, kalau itu didasarkan pada anggapan bahwa para pegawai lembaga tersebut tidak akan menunaikan zakat kalau tidak diambil langsung, tapi kalau didasarkan pada penataan manajemen zakat yang baik demi terwujudnya manfaat zakat yang optimal bagi mustahiq, itu lebih bisa diterima. Karena menurutnya makna kata "khudz" dalam Q.S. at-Taubah : 103 harus

${ }^{27}$ Wawancara dengan Dr. H. Muzakki .... dilihat konteksnya dulu..$^{28}$

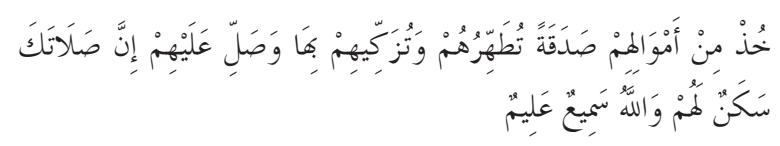

Artinya: Ambillah zakat dari sebagian harta mereka, dengan zakat itu kamu membersihkan dan mensucikan mereka dan mendoalah untuk mereka. Sesungguhnya doa kamu itu (menjadi) ketenteraman jiwa bagimereka. dan Allah Maha mendengar lagi Maha mengetahui.

Terkait dengan pemahamannya terhadap ayat tersebut Muzakki mengungkapkan bahwa:

"Ayat tersebut harus diberlakukan sesuai dengan konteks. misalnya, ada orang kaya bakhil, tidak mau mengeluarkan zakat, maka khalifah bisa melakukan tindakan paksa untuk mengambil zakat orang tersebut. sedangkan untuk konteks sebuah lembaga, seluruh pegawainya belum tentu dia seorang muzakky (orang yang wajib mengeluarkan zakat), karena belum tentu gaji yang dia dapatkan mencukupi kebutuhannya. Jadi kewajiban zakat itu tidak dilihat dari profesinya, tetapi mempertimbangkan cukup atau tidaknya kebutuhan tiap bulan, dan apakah kelebihan harta yang dia punya dalam setahun mencapai nishab atau tidak. Tukang becak bisa saja dia adalah muzakky karena bagi dia hidupnya sudah cukup, anak-anaknya juga tidak membutuhkan biaya sekolah, dan dia mempunyai kelebihan dari yang cukup setelah diambil kebutuhan sehari-hari. Sedangkan pegawai bisa saja menjadi mustahik, misalnya karena dia belum punya rumah, penghasilannya hanya cukup untuk kebutuhan pokok sehari-hari karena harus membiayai anak-anak yang masih kuliah". ${ }^{29}$

\section{Elit Agama Majlis Ulama Indonesia (MUI)}

Subyek penelitian yang berasal dari MUI, sama halnya dengan Muhammadiyah dan NU, penentuannya didasarkan pada rekomendasi dari pengurus MUI cabang Malang. Adapun subyek penelitian yang mewakili MUI dalam penelitian ini adalah Dr. Hj. Tutik Hamidah dan Dr. M. Mujab.

Dr. Hj. Tutik Hamidah lahir di Lamongan 23 April 1959, beliau adalah dosen tetap Fakultas Syariah UIN Maulana Malik Ibrahim Malang. Pendidikan S1 diselesaikan di Fakultas Tarbiyah IAIN Sunan Ampel Malang dan untuk S2 diselesaikan di Program Studi Agama dan

${ }^{28}$ Wawancara dengan Dr. H. Muzakki ....

${ }^{29}$ Wawancara dengan Dr. H. Muzakki... 
Filsafat IAIN Sunan Kalijaga Yogyakarta. Adapun gelar Doktor beliau peroleh dari UIN Syarif Hidayatullah Jakarta. Saat ini beliau sedang menjabat sebagai Dekan di Fakultas Syariah UIN Maulana Malik Ibrahim Malang. Dalam jajaran kepengurusan MUI kota Malang beliau dipercaya sebagai anggota komisi pendidikan dan dakwah.

Dr. H. M. Mujab, MA. Lahir di Blitar 21 November 1966. Beliau adalah dosen tetap Fakultas Tarbiyah UIN Maulana Malik Ibrahim Malang. Pendidikan SI ditempuh di Jami'ah Darul Uloom India, sedangkan pendidikan S2 dan S3 diselesaikan di Aligarh Muslim University India. Saat ini beliau dipercaya sebagai pengurus MUI di komisi Fatwa dan Ekonomi Syariah.

Majelis Ulama Indonesia melalui fatwa No.3 Tahun 2003, menegaskan bahwa semua bentuk penghasilan yang halal wajib dikeluarkan dengan zakatnya telah mencapai nishab dalam satu tahun, yaitu senilai 85 gram emas. Maka demikianjuga, Tutik Hamidah sebagai pengurus MUI cabang Malang ketika diminta pendapatnya tentang hukum zakat penghasilan yang berasal dari profesi mengatakan bahwa:

"Penghasilan dari profesi adalah Wajib Zakat berdasarkan pada hadis yang dikemukakan Yusuf Qardhawi, yaitu bahwa ada para sahabat yang diberi gaji atau ujrah dari baitul mâl langsung dipotong 2,5 $\%$ oleh khalifah. Zakat profesi diqiyashkan dengan zakat pertanian dan zakat perdagangan melalui metode Qiyash Syabah, yang menganalogkan pada dua ashl yang berbeda". Untuk prosentase zakat penghasilan, diqiyashkan pada tijarah yaitu 2,5\%, sedangkan nishab dan waktu pengeluarannya diqiyaskan dengan pertanian. Hal inidisebabkan adanya 'illah hukum yang berbeda. Nishab dan waktu pengeluaran diqiyashkan pada pertanian karena menurut pengalaman hasilnya bisa dipastikan. Misalnya, orang menanam padi, menurut pengalaman tiga bulan kemudian bisa panen, Sama seperti pegawai, guru, dosen, hakim, dokter menerima penghasilan secara rutin dan bisa dipastikan, bahkan lebih pasti dari hasil pertanian. Oleh sebab itu, dari sisi menerimanya disamakan dengan dzira'ah (pertanian). ${ }^{30}$

\footnotetext{
${ }^{30}$ Wawancara dengan Dr. Hj. Tutik Hamidah pada tanggal 22 Oktober 2011 di Ruang Dekan Fakultas Syariah UIN Maulana Malik Ibrahim Malang
}

Prosentase zakat penghasilan yang harus dikeluarkan disamakan dengan tijarah, karena untuk menjadi dosen, hakim, dokter juga perlu biaya, perlu peningkatan pengetahuan, perlu transportasi, sama halnya dengan tijarah (perdagangan) yang memerlukan modal dan mempunyai kadar kesulitan dan resiko yang tidak kecil. Dalam fiqh zakat, karena tijarah kadar resiko dan kesulitannya lebih besar dibanding pertanian, maka zakatnya kecil, jadi ada kecenderungan bahwa prosentase itu disesuaikan dengan kadar resiko yang harus ditanggung pemilik harta.

Senada dengan Tutik Hamidah, M. Mujab menyatakan bahwa:

"Zakat Profesi dapat disamakan dengan tijarah (perdagangan) menggunakan Qiyash Aulawi. Dengan demikian, profesi itu wajib di zakati, karena di dalam harta kita terhadapat hak orang-orang fakir. Rasanya naif kalau ada orang yang mendapatkan gaji diatas 5-10 juta kalau tidak mengeluarkan zakat karena menganggap profesi tidak dapat disamakan dengan perdagangan karena tidak mempunyai modal, menurut saya profesi itu ada modalnya, yaitu keahlian para pelaku profesi adalah modalnya". ${ }^{31}$

Sebenarnya apabila dirunut lebih dalam kenapa para pelaku profesi merasa keberatan kalau penghasilan dari profesi dimasukkan dalam harta yang wajib zakat, adalah karena di Indonesia orang Islam akan mempunyai beban ganda atau 2 kewajiban, yaitu pajak dan zakat. Bagi orang non Muslim yang tidak mempunyai kewajiban zakat, tidak ada masalah karena mereka cukup hanya dengan mengeluarkan pajak. Hal inilah kemudian yang mendorong orang Islam yang mengetahui kewajiban zakat, untuk mencari-cari dalil yang tidak mewajibkan zakat profesi dikarenakan beratnya menanggung 2 hal tersebut Zakat dan Pajak. Namun ada juga yang menyiasatinya dengan meniatkan sebagai zakat bagi harta yang terkena pajak, dengan begitu mereka berarti sudah menunaikan kewajiban zakat ketika mereka membayar atau dipotong pajak untuk

${ }^{31}$ Wawancara dengan Dr. M. Mujab pada tanggal 23 Oktober 2011 di Pasca Sarjana UIN Maulana Malik Ibrahim Malang 
setiap penghasilan dari profesi tersebut.

Lebih lanjut M. Mujab juga menjelaskan bahwa orang mengeluarkan zakat esensinya adalah untuk membersihkan harta, karena di dalam harta yang kita peroleh ada hak fakir miskin yang harus kita keluarkan. ${ }^{32}$ Sebagaimana firman Allah QS. Adz-Dzariat: 19

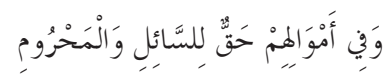

Artinya: Dan pada harta-harta mereka ada hak untuk orang miskin yang meminta dan orang miskin yang tidak mendapat bagian".

Bahkan dalam ayat lain Allah SWT menegaskan bahwa salah satu indikator agar seseorang dikategorikan sebagai orang mukmin adalah menunaikan zakat. Karena hal itu menjadi indikator untuk seseorang dapat dikatakan mukmin, maka seharusnya juga menjadi motivasi atau memunculkan kesadaran bagi Muslim untuk menunaikan zakat termasuk zakat penghasilan dari profesi. Q.S. Al-Mukminun : 1-4.

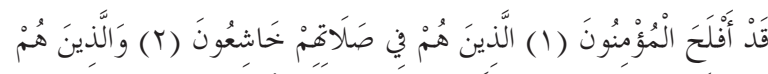

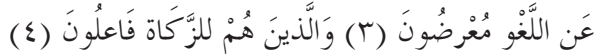

Artinya: Sesungguhnya beruntunglah orang-orang yang beriman, (yaitu) orang-orang yang khusyu> dalam sembahyangnya, dan orang-orang yang menjauhkan diri dari (perbuatan dan perkataan) yang tiada berguna, dan orang-orang yang menunaikan zakat.

\section{Menentukan Nishab dan Prosentase Zakat Elit Agama Muhammadiyah}

Sama halnya dengan nash yang digunakan sebagai dalil kewajiban zakat yang beragam, dalam menentukan nishab profesi para elit agama mempunyai beberapa pendapat. Karena memang tidak ada nash yang menjelaskan ini jadi kebanyakan para elit agama menggunakan qiyas. Sebagaimana yang disampaikan Bapak Abdul Haris:

"Saya lebih cenderung mengikuti ulama yang mengqiyashkan nishab zakat penghasilan dari profesi

\footnotetext{
${ }^{32}$ Wawancara dengan Dr. M. Mujab.....
}

pada nishab zakat mâl yaitu senilai 85 gram emas. Begitu juga dengan prosentasi yang harus dikeluarkan sebagai zakatnya, yaitu $2,5 \% .^{33}$

Selanjutnya terkait dengan prosentase yang harus dikeluarkan dari zakat profesi Abdul Haris menjelaskan:

"Kalau di lembaga ini (Universitas Muhammadiyah Malang)penghasilan sayasebagaidosensudahdipotong sebesar 2,5\%. Namun, secara pribadi saya juga tetap mengeluarkan 2,5\% di luar lembaga ini. Mengapa saya gunakan prosentase zakat perdagangan, karena sulit rasanya mengqiyashkan pada zakat pertanian, sebab kita tidak bisa menggolongkan apakah usaha atau pekerjaan yang kita lakukan termasuk mengeluarkan biaya atau tanpa biaya, kalau dipertanian kan jelas, jika diairi dengan air hujan maka wajib zakat $10 \%$, sedangkan kalau pupuknya beli, air untuk kepentingan irigasi juga beli maka zakatnya 5\% saja". ${ }^{34}$

Adapun tentang penghitungannya, menurut Abdul Haris pada dasarnya nishab zakat dihitung dan dikeluarkan setelah dikurangi kebutuhan pokok sehari-hari, dan hasil bersihnya itulah yang dikeluarkan zakat. Tetapi dalam prakteknya beliau mengeluarkan zakat dari penghasilan Bruto yang dia peroleh dari profesinya sebagai dosen yang telah dipotong langsung oleh lembaganya, bahkan beliau masih mengeluarkannya lagi sendiri sebanyak 2,5\%. Jadi total zakat yang dikeluarkan oleh Abdul Haris adalah 5\% dari setiap penghasilan yang diperoleh dari profesinya tanpa memperhitungkan lagi nishab dan haul-nya. ${ }^{35}$

Tidak berbeda dengan Abdul Haris, Sunkanah mengatakan bahwa:

"Nishab untuk zakat penghasilan senilai 85 gram emas dengan jangka waktu satu tahun. Akan tetapi karena emas berubah-ubah harganya, sehingga tidak bisa dipastikan berapa jumlah rupiahnya. Misalnya 1 gramnya 400 ribu maka nishabnya senilai 34 juta. Tetapi nishab ini akan menimbulkan masalah, apa lagi untuk PNS golongan menengah ke bawah, akan

\footnotetext{
${ }^{33}$ Wawancara dengan Abdul Haris.....

${ }^{34}$ Wawancara dengan Abdul Haris.....

${ }^{35}$ Wawancara dengan Abdul Haris.....
} 
sulit mencapai nishab, apalagi misalnya dia sebagai dosen Luar Biasa di UMM seperti saya ini, terlebih apabila dosen tersebut tidak memiliki profesi lain yang membantu, jelas tidak mungkin bisa zakat. Jadi kalau menggunakan pendapat ini tidak ada orang yang zakat, kecuali atas dasar kesadaran pribadi. Oleh karena itu, berapapun penghasilan yang saya terima akan saya keluarkan zakatnya, dan saya menggunakan standar penghasilan yang saya peroleh tanpa mempertimbangkan nishab-nya, karena kalau menggunakan nishab dengan standar emas 85 gram saya tidak akan zakat, karena termasuk penghasilan yang belum mencapai nishab dan tidak terkena wajib zakat."

SelanjutnyaSunkanahjuga menjelaskan tentang prosentasi zakat yang dikeluarkannya:

"Di UMM hampir semua dosen dipotong 2,5\% meskipun hanya mengajar 2 sks, seperti saya paling banyak kan dapat 100 ribu ditambah transport, THR, dan insentif UTS. Kalau sebagai PNS dulu-Hakim pengadilan agama- gaji saya tidak pernah dipotong, tetapi saya kumpulkan berapa uang yang saya peroleh kemudian saya keluarkan zakatnya. Kalau gaji saya di UMM sudah dipotong 2,5\% saya pikir lebih enak dan menguntungkan saya, karena uang saya sudah bersih. Kalau saya menerima pemberian atau hadiah saya keluarkan zakatnya $20 \%$, dan tidak perlu saya kurangi dengan kebutuhan saya". ${ }^{36}$

Paparan data diatas memberi pengertian bahwa pada umumnya para pelaku profesi dikalangan Elit agama Muhammadiyah telah menunaikan kewajiban zakat profesi dengan tanpa mempertimbangkan nishab dan haulnya, walaupun dalam teorinya mereka berpendapat bahwa mereka mengikuti pendapat yang mingqiyashkan nishab zakat profesi dengan zakat mal yaitu 85 gram emas. Sedang untuk prosentasenya berkisar antara $2,5 \%-5 \%$, ini juga disesuaikan dengan prosentasi zakat mal tapi mereka masih menambahkannya.

\section{Elit Agama Nahdlatul Ulama}

Untuk masalah nishab dan haul ternyata memang tidak begitu menjadi pertimbangan para elit agama, sebagaimana yang diungkapkan oleh KH. Dahlan:
"Saya memandang bahwa zakat itu wajib meskipun belum memenuhi nishab-nya. Kalau secara umum penghasilan yang saya terima sudah wajib zakat karena sudah melebihi nishab, baik zakat pertanian maupun emas. Contoh, gaji pokok saya Rp. 3.000.000, kemudian sertifikasi dapat Rp. 3.000.000, tunjangan jabatan Rp. 1.000.000, maka totalnya dalam satu bulan adalah $R p$. 7.000.000, dalam satu tahun total gaji pokok saya Rp. 7.000.000, x 12 bulan berarti sama dengan Rp. 84.000.000. apabila kita qiyashkan dengan nishabnya emas adalah 85 gram dan andaikan 1 gram emas seharga Rp. 400 ribu maka nilai nishab ini adalah $R p .34 .000 .000$, berarti itu kan sudah melebihi nishab. Penghasilan itu belum ditambah dengan penghasilan saya yang lain. Prosentase zakat itu bergeser minimal 2,5\% hingga 33,333\% atau sepertiga harta. Tetapi yang sering digunakan adalah 2,5\% dari penghasilan. Dan untuk penghitungannya, penghasilan yang saya terima langsung saya zakati tanpa menghitung kebutuhan saya."

Sedangkan menurut Ustadz Muzakki ketika diminta pendapatnya tentang nishab zakat profesi, beliau mengatakan:

"Karena saya dari berasal dari kalangan pondok pesantren, maka saya tidak bisa merubah yang sudah jelas. Bagi saya zakat penghasilan itu harus ada haul dan punya uang senilai 85 gram emas (nishab), dan sebenarnya saat ini penghasilan yang saya peroleh dari profesi sebagai dosen belum mencapai nishab karena hanya cukup untuk memenuhi kebutuhan pokok sehari-hari, bahkan saya juga masih menanggung hutang, tetapi saya sudah mengeluarkannya zakat saya sebanyak $2,5 \%$ setiap bulannya dengan dipotong langsung oleh lembaga, yaitu UIN Maulana Malik Ibrahim Malang, dan itu tanpa memperhitungkan nishab dan haul-nya."37

Selanjutnya Ustad Muzakki juga menjelaskan tentang prosentase zakat yang beliau keluarkan selain yang dipotong langsung oleh lembaga tempatnya bekerja:

"Selain 2,5\% yang dipotong langsung oleh lembaga, tidakadaprosentaseyang pastiuntukzakatpenghasilan yang saya keluarkan, tergantung saya punya rezeki berapa dan juga tergantung kepada kebutuhan yang akan saya jadikan mustahiq, contohnya, kalau saudara yang sudah punya anak saya kasih 500 ribu, kalau baru nikah saya kasih 100 ribu, sedangkan keponakanponakan yang belum menikah saya kasih 50 ribu". 
Walaupun secara penghitungan wajib zakat itu adalah penghasilan yang diterima dikurangi kebutuhan, dan apabila dalam waktu satu tahun sudah melebihi nishab maka dia wajib zakat, jika belum maka tidak wajib. Tetapi karena kesadaran dan pertimbangan rasa keadilan orang yang mempunyai kesadaran agama yang baik akan mengeluarkan zakat penghasilan dari profesi tanpa mempertimbangn nishab dan haul, juga tanpa dikurangi kebutuhan pokok. Mereka mengeluarkan zakat minimal 2,5\% dari penghasilan bruto bukan netto.

\section{Elit Agama Majlis Ulama Indonesia (MUI)}

Mengenai nishab, haul, dan prosentase zakat profesi Tutik Hamidah berpendapat bahwa:

"Nishab zakat profersi sama dengan zakat pertanian, zakat penghasilan yang rutin saya keluarkan sebesar 2,5\%. Adapun cara penghitungannya, penghasilan yang saya terima tiap bulan saya total, selain yang sudah dipotong oleh UIN lewat el-Zawa, misalnya gaji sertifikasi itu beda dengan gaji pokok, karena diberikan dua bulan sekali atau tiga bulan sekali, setelah saya total saya keluarkan 2,5\%, untuk kehati-hatian saya lipatkan lagi dua kali, misalnya saya perkirakan zakat saya 100 ribu, saya kalikan 2 menjadi 200 ribu. Meskipun demikian, kadang-kadang saya juga mengeluarkan 5-10\% dari penghasilan saya".

Sedangkan ketika ditanyaapakahyang dihitung bruto atau netto beliau menjelaskan:

"Penghitungan zakat tersebut tidak saya kurangi dengan pengeluaran atau kebutuhan-kebutuhan sehari-hari. Menurut saya, zakat senilai 2,5\% itu tidak seberapa besar dan saya tidak merasa berat. Selama ini yang saya praktikkan, sebelum saya gunakan untuk kepentingan yang lain, saya zakati dulu. Apabila saya hitung kebutuhan saya, baik untuk pendidikan, transportasi, makan, mengikuti rasa ingin memiliki sesuatu, tanggungan hutang, justru lebih ruwet dan malah tidak jadi zakat."

Kesadaran akan kewajiban zakat yang dimiliki oleh beliau juga didasarkan pada pemahaman bahwa zakat itu dalam al-Qur'an perintahnya sangat kuat, yang hal itu terlihat dari redaksi ayat, dimana setiap ada perintah sholat pasti selalu dibarengi dengan perintah zakat, yang itu berarti kewajiban zakat sama dengan kewajiban shalat.
Adapun menurut M. Mujab nishab zakat profesi mengikuti zakat tijarah, yaitu senilai 85 gram emas, tetapi dalam prakteknya ketika mengeluarkan zakat profesi tanpa mempertimbangkan nishab dan haul. Sebagaimana gaji beliau yang sudah langsung dipotong 2,5\% oleh el-Zawa lembaga zakatnya UIN Maulana Malik Ibrahim Malang setiap bulan ketika menerima penghasilan dari profesinya sebagai dosen, juga tanpa menghitung apakah sudah sampai satu nishab atau tidak. Selain itu untuk penghasilan yang didapat di luar gaji di UIN beliau mengatakan:

"Saya mengeluarkan zakat profesi sebesar 2,5\% bahkan lebih untuk zakat penghasilan di luar universitas dan sebagai bentuk kehati-hatian. Zakat penghasilan tidak perlu dikurangi kebutuhan karena penghitungannya akan sulit, selain itu kalau dikurangi akan habis digunakan untuk kebutuhan sehari-hari, dan tidak jadi zakat. Bagi saya 2,5\% itu tidak berat".

Ketika diminta untukmenerangkan bagaimana cara beliau dalam menghitung prosentase zakat profesi yang harus dikeluarkan beliau menjawab:

"Untuk perhitungannya, misalnya gaji saya per bulan 6-7 juta $x 12$ kemudian saya ambil 2,5\% nya sering kali lebih dari pada itu. Lebih praktisnya begini jika gaji saya 12 bulan, maka satu bulannya bukan hak saya dan saya berikan secara langsung (sekitar 7,5 \%)." .

Dari pemaparan di atas dapat dianalisa bahwa ketika masih berbicara tentang teori seseorang masih berada dalam kerangka teks, tetapi ketika berada dalam dataran aplikasinya seseorang menjadi pragmatis. Dalam kasus zakat hal itu terlihat ketika ditanya tentang nishab dan prosentase semua mengatakan bahwa nishab zakat profesi sama dengan zakat mal dan tijarah yaitu senilai 85 gram emas dan dalam waktu satu tahun (mencapai haul), sedangkan prosentase zakat yang harus dikeluarkan adalah 2,5\%. Tetapi setelah ditanyakan bagaimana aplikasi yang dilakukan oleh subjek peneliti, semuanya mengeluarkan zakat profesi tanpa mempertimbangkan nishab dan haul-nya, sedangkan untuk prosentasenya fleksibel berkisar antara 2,5\% - 7,5 \% karena 
alasan praktis dan kondisional. Untungnya dalam persoalan zakat ini pragmatisme subjek peniliti mengarah kepada yang lebih baik daripada teori yang didasarkan pada teks.

\section{Penentuan Waktu dan Mustahiq Zakat}

\section{Elit Agama Muhammadiyah}

Dalam pembahasan tentang waktu mengeluarkan zakat profesi, seharusnya dikaitkan dengan nishab dan haul, karena sebagaimana sudah dijelaskan diatas bahwa kewajiban zakat profesi adalah apabila mencapai nishab dalam waktu satu tahun, dan juga ada perdebatan tentang penghitungannya apakah netto atau bruto. Menurut Syaikh H. Purnomo, zakat profesi tidak dapat di ambil apabila belum 1 tahun. Sedangkan menurut Masfuk, boleh diambil tetapi dihitung kebutuhan satu bulan baru sisanya diambil $2,5 \%$, berarti zakat profesi diambil dari netto. Adapun menurut contoh yang diberikan oleh Departemen Agama, zakat profesi ini diambil dari gaji kotor (bruto).

Namun, dalam praktiknya para elit agama yang memiliki kesadaran tinggi akan prinsip keadilan dan proses penyucian dalam kewajiban zakat, tidak lagi mempermasalahkan hal tersebut. Sebagian besar dari mereka memilih menunaikan langsung zakatnya pada saat menerima penghasilan dari profesi mereka. Sebagaimana yang diungkapkan Abdul Haris :

"Menurut saya, zakat penghasilan tidak menggunakan haul jadi setiap menerima harus dikeluarkan. Zakat penghasilan ini saya salurkan secara langsung, sebab jumlah tidak terlalu banyak, kemudian lebih simple, jika melalui lembaga harus cari dulu lembaganya, LAZIZ miliknya Muhammadiyah Kota Malang belum berjalan dengan baik, karena memang baru dirintis dan masih dalam proses penataan."

Menurut Sunkanah, dia juga memilih mengeluarkan zakat profesi langsung setiap menerima gaji, lebih detainya beliau mengatakan:

"Uang pensiun yang saya terima dalam 1 bulan saya keluarkan zakatnya 2,5\%, misalnya 2 juta atau 3juta, saya ambil 75 ribu atau lebih, saya memilih melebihkan karena takut kurang. Saya memilih mengeluarkan per bulan biar tidak merasa berat". ${ }^{38}$

Selanjutnya Sunkanah juga menjelaskan bagaimana proses penghitungan zakatnya,

"Zakat penghasilan ini saya hitung dalam jangka waktu satu tahun. Misalnya saya memulai menabung dari bulan Ramadhan maka saya akan mengeluarkan zakat pada bulan Ramadhan berikutnya. Sebelumnya, saya keliling-keliling, untuk melihat uang simpanan saya yang ada di bank atau koperasi. Baik dari gaji yang saya peroleh atau insentif dari UMM, atau ketika saya dapat arisan, sebab biasanya yang saya masukkan tabungan belum saya keluarkan zakatnya. Saya hitung semua total penghasilan saya dalam satu tahun setiap menjelang puasa. saya hitung berapa yang sudah dikeluarkan dan berapa kurangnya. Jadi bukan sekedar ngawur, ini wajib zakat jangan sampai tidak mengeluarkan. Misalnya setelah saya hitung seluruh penghasilan selama satu tahun, ternyata saya harus mengeluarkan zakat 2 juta, padahal setiap bulan saya baru mengeluarkan 100 ribu yang berarti totalnya 1,2 juta, jadi zakat yang harus saya keluarkan masih kurang 800 ribu". Jadi meskipun hitungannya satu tahun, tetapi zakat ini sudah saya keluarkan setiap bulannya, jadi diakhir tahun tinggal menyempurnakannya."

Waktu untuk mengeluarkan zakat yang dipilih Sunkanah ada 2, untuk penghasilan tetap yang dia terima dikeluarkan setiap bulan pada saat menerima, sebelum digunakan untuk kebutuhan sehari-hari. Sedang untuk penghasilan yang sifatnya insidentil dia keluarkan setiap tahun setelah uang itu ditabung.

Mengenai mustahiq yang dipilih untuk menerima zakatnya Abdul Haris mengatakan: Zakat saya berikan pada perorangan terutama tetangga atau kerabat yang membutuhkan, kerabat ini adalah saudara yang berhak menerima, karena masuk katagori miskin misalnya. Alasannya, ada tiga aspek yang terpenuhi, ibadahnya, hubungan sosial, dan hubungan kekerabatan juga terbina. Hal ini juga mempererat hubungan dengan tetangga, itu kan ajaran agama untuk mengutamakan yang terdekat. Ada juga hadits yang menjelaskan bahwa bersedekah untuk keluarga lebih baik dari pada membangun masjid. Meskipun demikian kadang-kadang zakat penghasilan

${ }^{38}$ Wawancara dengan Sunkanah... 
ini juga saya salurkan melalui lembaga yang membutuhkan, untuk keperluan sabilillah, sekolahan, kadang juga masjid. Jadi tergantung kepentingan masyarakat. ${ }^{39}$

\section{Elit Agama Nahdlatul Ulama}

Menurut KH. Dahlanzakat profesi dikeluarkan secara langsung artinya tidak menunggu hingga mencapai nishab, karena kita tidak sempat menghitung berapa jumlah penghasilan dalam satu tahun. Kalau menunggu hingga haul maka zakat yang dikeluarkan begitu banyak, oleh karena itu kita setiap hari mengeluarkan zakat biar tidak terasa berat. Selain itu, secara pribadi kami belum sempat me-manage zakat penghasilan. Apabila menunggu hingga satu tahun, saya khawatir malah tidak bisa membayar zakat, karena digunakan untuk kepentingan lain padahal semestinya sudah wajib mengeluarkan zakat.

Sedangkan menurut Muzakki, walaupun dia merasa tidak termasuk wajib zakat kalau mempertimbangkan nishab, beliau memilih mengeluarkan zakat penghasilan pada saat menerima dan disesuaikan dengan kondisi. Sedangkan untuk prosentasenya tergantung rizki yang dia terima dan kondisi dari saudara dan kerabatnya yang menjadi mustahiq. Misalnya, ketika Muzakki mendapat rizki yang lebih. saudara yang sudah punya anak mendapat 500 ribu, kalau baru nikah mendapat 100 ribu, dan keponakan yang belum berumah tangga hanya mendapat 50 ribu.

Dalam penentuan mustahiq ketika hendak menyalurkan zakat profesinya KH. Dahlan mengatakan: Saya memilih menyalurkan zakat penghasilan pada perorangan secara langsung, misalnya ada anak kecil dari keluarga tidak mampu lansung saya beri uang, atau saya undang tetangga sekitar untuk melakukan pengajian di rumah dan saya sediakan makan untuk kurang lebih 200 orang.

Mustahiq yang dipilih Ustad Muzakki sebagai penerima zakat adalah saudara dan kerabatnya, sebagaimana pernyataan beliau: Sebagian harta dari penghasilan, saya berikan

${ }^{39}$ Wawancara dengan Abdul Haris... pada kerabat dekat dulu, dan selama kerabat masih ada, saya tidak memberikan kepada orang lain. Muzakki juga lebih senang memberikan zakatnya kepada saudaranya yang punya usaha, misalnya pedagang, tujuannya biar kerabatnya mempunyai tambahan modal untuk usaha perdagangannya. Inilah yang menurut beliau penyaluran zakat produktif bukan konsumtif, dan bermanfaat untuk jangka panjang.

\section{Elit Agama Majlis Ulama Indonesia (MUI)}

Menurut Tutik Hamidah, penghasilan dari profesi dapat dipastikan perolehannya, seperti halnya petani yang panen, pegawai juga mendapat gaji setiap bulan. Sehingga setiap kali menerima gaji tanpa menunggu haul zakat profesi harus dikeluarkan. Selain itu, sebagai seorang pagawai yang tentu juga memiliki penghasilan yang lain selain gaji bulanan juga harus dikeluarkan sendiri zakatnya secara langsung.

Sedangkan menurut M. Mujab, Jika merujuk pada Qiyash tijarah maka zakat wajib dikeluarkan setelah satu tahun, akan tetapi boleh mendahulukan atau mencicilkan pembayaran zakat, dengan catatan berapa zakat yang harus dikeluarkan dalam satu tahun dihitung secara keseluruhan, pengeluaran zakat setiap satu bulan akan memudahkan penghitungan per satu tahun dan lebih meringankan.

Selanjutnya dalam penyaluran zakat yang dikeluarkannya Tutik Hamidah menjelaskan, bahwa selain yang telah disalurkan ke el-Zawa oleh lembaga tempatnya bekerja, beliau memilih untuk memberikan zakat profesinya kepada para tetangga yang sudah tua, janda-janda tua yang perlu disantuni, dan anak-anak yatim yang miskin dan masih usia sekolah untuk membantu biaya sekolah mereka. Lebih lanjut beliau juga menyatakan kalau zakat profesinya sebagian juga disalurkan melalui BAZIS, yang kemudian disalurkan ke madrasah atau guru-guru TPQ.

Adapun tentang alasan pemilihan mustahiq sebagaimana disebutkan sebelumnya Tutik Hamidah mengatakan:

“Tujuannya penyaluran zakat ke berbagai 
kalangan adalah untuk menjalin hubungan baik dengan tetangga, terlebih lagi banyak tetangga saya yang kondisinya sudah tua, sakit-sakitan, miskin, dan anak-anaknya juga biasa-biasa saja. Mereka senang sekali dan merasa diperhatikan ketika menerima zakat tersebut, bahkan saya didoakan untuk kebaikan saya dan keluarga".

Menurut M. Mujab pendistribusian zakat agak sulit karena lembaga yang mengelola zakat overlapping dan terlalu banyak, setiap tahun beliau mendapatkan 5-7 permintaan zakat dari berbagai lembaga, tidak hanya lembaga amil zakat yang resmi, tetapi juga sekolah dan masjid. Belum lagi permintaan dari lembaga atau organisasi masyarakat tempat seseorang itu berafiliasi. Akhirnya sebagai solusinya beliau menjelaskan:

"Ketika saya sebagai pegawai negeri, saya menginduk pada kebijakan lembaga tempat saya bekerja yaitu UIN Maulana Malik Ibrahim Malang, yang menyalurkan zakat melalui el-Zawa (Lembaga Zakat dan Wakaf milik UIN), sedangkan untuk penghasilan diluar gaji yang sudah dipotong langsung zakatnya oleh UIN, saya menyalurkannya kepada perorangan, tetangga dan saudara yang termasuk mustahiq, Persoalannya karena adanya ketidak percayaan kepada lembaga, dan juga untuk menanamkan pengaruh pada masyarakat".

Persoalan ketidakpercayaan kepada lembaga adalah sesuatu yang perlu dicarikan solusinya, karena hal tersebutlah yang mengakibatkan potensi zakat yang sangat besar tidak dapat dijadikan pendukung yang kuat dalam upaya mengentaskan kemiskinan. Padahal itu adalah tujuan utama dari diwajibkannya zakat.

Apabila dianalisa dengan menggunakan teori konstruksi sosial Peter L. Berger, maka dapat dideskripsikan konstruk sosial elit agama kota Malang tentang zakat sebagai berikut:

Pertama, proses eksternalisasi terjadi ketika elit agama berupaya memahami tentang zakat profesi, nishab dan prosentasenya berdasarkan teks dan pendapat berbagai ulama, tanpa upaya melibatkan diri dan kondisi sosialnya, maka hasilnya mereka menetapkan bahwa zakat profesi hukumnya wajib bagi penghasilan yang diperoleh dari profesi tertentu yang mencapai nishab dalam waktu satu tahun. Jadi untuk yang tidak mencapai nishab walau hidupnya sudah sangat berkecukupan dan tetangganya masih banyah yang membutuhkan bantuannya tidak terkena wajib zakat. Kedua, proses objektivasi terjadi ketika elit agama dalam merealisasikan zakat profesi ternyata tidak lagi mempertimbangkan nishab dan haul tetapi karena rasa sosial yang dimilikinya dan pertimbangan keadilan. Mereka mengeluarkan zakat profesi sebesar 2,5\% setiap menerima penghasilan tanpa memperdulikan apakah dia termasuk wajib zakat atau tidak, dan juga tanpa mempertimbangkan nishab dan haul.

Ketiga, proses internalisasi terjadi ketika para elit agama dikarenakan sikap keberagamaan yang kuat, rasa social yang tinggi dan kondisinya yang lebih baik dibanding lingkungan sekitarnya walaupun dia tidak termasuk orang kaya, mereka mengeluarkan zakat profesi tanpa menghitung prosentase yang diwajibkan baginya. Mereka mengeluarkan zakat kepada setiap orang yang membutuhkan, bahkan sampai mencapai 10\% - $20 \%$ sesuai dengan kondisi yang dihadapinya dan untuk upaya ihtiyat (kehati-hatian), tetapi yang pasti lebih dari 2,5\% yang menjadi kewajibannya.

\section{Kesimpulan}

Setelah melakukan pemaparan hasil penelitian dan analisis data, sesuai dengan rumusan penelitian yang diajukan di awal, peneliti menarik beberapa kesimpulan bahwa Zakat profesi menurut elit agama kota Malang adalah zakat yang wajib dikeluarkan oleh seseorang dengan penghasilan tertentu setelah mencapai nishab dan haul (dalam jangka waktu satu tahun). Konstruks elit agama kota Malang terhadap zakat profesi adalah: a) Semua subyek penelitian, baik dari Muhammadiyah, Nahdlatul Ulama', dan Majelis Ulama' Indonesia menyatakan bahwa zakat profesi hukumnya wajib. Hal ini didasarkan atas keumuman lafadz tentang perintah zakat dalam al-Qur'an dan qiyas aulawi terhadap lafadz tentang perintah zakat pertanian; b) Dalam menentukan nisab untuk zakat profesi semua berpandangan bahwa zakat profesi diqiyaskan dengan zakat 
emas dan perdagangan. Hanya saja terdapat perbedaan dalam prosentasenya. Muhammadiyah menyatakan bahwa prosentase zakat profesi sebanyak 2,5\%. Sedangkan dari Nahdlatul Ulama' menyatakan bahwa prosentasenya mulai 2,5\%-3,3\%. Sementara itu, untuk MUI terdapat dua pandangan, yaitu $2,5 \%$ dan 2,5\% - 5\% untuk kehatia-hatian (ihtiyâth); c) Tidak terdapat perbedaan pendapat di kalangan elit agama kota Malang terhadap waktu pelaksanaan zakat profesi, yaitu tidak menunggu nishab dan haul tetapi langsung pada waktu menerima penghasilan. Hanya saja subyek penelitian dari Majelis Ulama' Indonesia dan Muhammadiyah menambahkannya dengan cara mengulangi pembayaran zakat kembali pada akhir tahun untuk kehatihatian; d) Ketika mengeluarkan zakat profesi, semua subjek penelitian dalam menentukan mustahiq zakat cenderung memberikannya kepada saudara atau kerabatnya sendiri yang tidak mampu dan kepada para tetangga yang miskin. Adapun untuk mustahiq yang lainnya

\section{DAFTAR PUSTAKA}

A. Muhtadi Ridwan, "Aplikasi Pengelolaan Zakat pada Lembaga Zakat, Infaq, dan S\{adaqah (LAGZIS) Kota Malang", Tesis, UMM, Malang, 2003.

Abdul Ghofur Anshori, Hukum dan Pemberdayaan Zakat, Yogyakarta: Pilar Media, 2006.

Abdurrachman Qadir, Zakat dalam Dimensi Mahdhah dan Sosial, Jakarta: RadjaGrafindo Persada, 2001.

Abubakar, Irfan dan Chaider S. Bamualim, (editor). Filantropi Islam dan Keadilan Sosial, Studi tentang Potensi, Tradisi dan Pemanfaatan Filantropi Islam di Indonesia. Jakarta: Center for the Studi of Religion and Cultur, UIN Syarif Hidayatullah, 2006.

Ali Yafie, Menggagas Figh Sosial, Jakarta: Mizan,1994.

al-Zuhaili, Wahbah, al-Figh al-Islamiy wa Adillatuh. Damaskus: Dar al-Fikr, 2004. disesuaikan dengan permohonan atau amil yang mendatanginya.

\section{Saran}

Lembaga amil zakat agar meningkatkan profesionalismenya dalam mengelola zakat yang telah diterima, untuk mendapatkan kepercayaan dari masyarakat. Di samping itu, agar lebih aktif dalam mencari dan mendatangi mustahiq zakat yang tidak mempunyai waktu dan tidak terbiasa mengeluarkan zakatnya melalui lembaga atau badan amil zakat. Untuk peneliti selanjutnya bisa melakukan penelitian yang lebih mendalam dan dengan jangkauan yang lebih luas, sehingga akan menghasilkan penelitian yang akurat. Untuk lembaga Muhammadiyah, NU, dan MUI bisa melakukan kajian-kajian yang lebih mendalam tentang zakat profesi sehinga dapat menghasilkan kesimpulan yang lebih sistematis dan akurat, sehinga dapat disosialisasikan secara luas kepada seluruh anggota masyarakat dan menjadi pijakan masyarakat dalam mengaplikasikan zakat profesi.

Badan Pusat Statistik Indonesia, Dasar Analisis Kemiskinan, Jakarta: BPS, 2002.

Bambang Sunggono, Metodologi Penelitian Hukum, Jakarta: PT Raja Grafindo Persada, 2003.

Bamualim, Chaider S. dan Irfan Abubakar (editor), Revitalisasi Filantropi Islam, Jakarta: Pusat Bahasa dan Budaya UIN, Syarif Hidayatullah, 2005.

Departemen Agam RI, PolaPembinaan Lembaga Amil Zakat, Jakarta: Direktorat Pengembangan Zakat dan Wakaf, 2005.

Didin Hafidhuddin, Zakat dalam Perekonomian Modern, Jakarta: Gema Insani Press, 2002.

Dr.Anton Bakker, Metode-Metode Filsafat, Jakarta: Ghalia Indoneesia, 1984.

Endang Turmudi, Perselingkuhan Kiai dan Kekuasaan, Yogyakarta: LKiS, 2004.

Engkus Kuswarno, Fenomenologi, Bandung: Widya Padjadjaran, 2009. 
Eri Sudewo, Manajemen Zakat, Tinggalkan 15 Tradisi, Terapkan 4 Prinsip Dasar, Jakarta: IMZ, 2004.

Hiroko Horikoshi, Kiai dan Perubahan Sosial, Jakarta: P3M, 1987.

Ilyas Supena dan Darmuin, Manajemen Zakat, Semarang: Walisanga Press, 2009.

Masdar Farid Mas'udi, Menggagas Ulang Zakat sebagai Etika Pajak dan Belanja Negara untuk Rakyat, Bandung: Mizan, 2005.

Muhammad Hadi, Problematika Zakat Profesi dan Solusinya, Sebuah Tinjauan Sosiologi Hukum Islam, Yogyakarta: Pustaka Pelajar, 2010.

Muhammad Soekarni, Peran Strategis Zakat dalam Fungsi Investasi Islam, dalam Investasi Syariah, Yogyakarta: Kreasi Wacana, 2008.

Multipiah, "Peran "ZIS" terhadap Kesejahteraan Rumah Tangga Miskin (StudiPenanggulangan Kemiskinan Melalui Bantuan Modal, Pendidikan dan Kesehatan di Daerah Malang)"', Disertasi, UNIBRAW, Malang, 2007.

Nur Syam, Bukan Dunia Berbeda, Sosiologi Komunitas Islam, Surabaya: Eureka, 2005.

Nuruddin Mhd. Ali, Zakat Sebagai Instrumen dalam Kebijakan Fiskal, Jakarta: RadjaGrafindo Persada, 2006.
Peter L. Berger dan Thomas Luckman, Tafsir Sosial atas Kenyataan: Risalah tentang Sosiologi Pengetahuan, Jakarta: LP3ES, 1991.

Sjechul Hadi Permono, Formula Zakat Menuju Kesejahteraan Sosial, Surabaya: Aulia, 2005.

Sudirman, "Relasi Zakat dan Pajak, Studi tentang Zakat sebagai Pengurang Penghasilan Kena Pajak (PKP)", Tesis, IAIN Syarief Hidayatullah, Jakarta, 2002.

UgiSuharto, Keuangan Publik Islam, Reinterpretasi Zakat dan Pajak, Yogyakarta: Pusat Studi Zakat, 2004.

Wahbah al-Zuhaili, al-Tafsir al-Munir, Jilid VI, Dar al-Fikr, Damaskus, 2003.

Yamin Haddad, "Dinamika Pengelolaan Zakat di Desa Putukrejo Gondanglegi Malang", Disertasi, IAIN Sunan Ampel, Surabaya, 2008.

Yusuf al-Qardlâwî, Fiqh al-Zakâh, Dirâsah Muqâranah Ahkâmuha wa Falsafatuhâ fi Dlauial-Qur'ân wa al-Sunnah. Damaskus: Dar al-Fikr, t.t.

Yusuf Qard\}awi, al-Ibâdah fi al-Islâm, Beirut: Muassasah al-Risalah, 1993.

Zamakhsari Dhafir, Tradisi Pesantren: Studi tentang Pandangan Hidup Kiai, Jakarta: LP3ES, 1982. 